$\xi_{3}=-1$

\title{
Performance of some jute $\&$ allied fiber varieties in the southern part of Bangladesh
}

\author{
K. M. Mehadi Hassan ${ }^{3}$, Md. Isfatuzzaman Bhuyan ${ }^{2}$,Mohammad Kabirul Islam ${ }^{1}$, Md. Fazlul Hoque ${ }^{1}$, Md. Monirul \\ Islam $^{1 *}$ Md. Sazedul Islam ${ }^{1}$, Mahbuba Ferdous ${ }^{1}$, Ram proshad $^{1}$ \\ ${ }^{1}$ Department of Soil Science, Patuakhali Science and Technology University, Dumki, Patuakhali,Dhaka, Bangladesh \\ ${ }^{2}$ Department of Agronomy, Bangladesh Agricultural University, Mymensingh, Dhaka,Bangladesh \\ ${ }^{3}$ Department of Agronomy, Patuakhali Science and Technology University, Dumki, Patuakhali,Dhaka, Bangladesh \\ *Corresponding author E-mail:monirulpstu1@gmail.com
}

\begin{abstract}
The present study was conducted to know the performance of growth, yield contributing parameters and yield of some Tossa and Deshi Jute and also some Allied fiber varieties at the agronomy field laboratory during the period from March to September 2012. Twelve Jute and Kenaf vareities viz. CVL-1 ( $\left.\mathrm{V}_{1}\right), \mathrm{HC}-2\left(\mathrm{~V}_{2}\right), 0-9897\left(\mathrm{~V}_{3}\right), \mathrm{CVE}-3\left(\mathrm{~V}_{4}\right), 0-72\left(\mathrm{~V}_{5}\right), \mathrm{BJC}-7370\left(\mathrm{~V}_{6}\right), \mathrm{HC}-95\left(\mathrm{~V}_{7}\right), \mathrm{BJC}-83\left(\mathrm{~V}_{8}\right), \mathrm{VM}-1\left(\mathrm{~V}_{9}\right)$, 0-795 $\left(\mathrm{V}_{10}\right), \mathrm{HC}-3\left(\mathrm{~V}_{11}\right)$, BJC-2142 $\left(\mathrm{V}_{12}\right)$ were taken and catagorized into three viz. Deshi $\left(\mathrm{V}_{1}\right.$ to $\left.\mathrm{T}_{5}\right)$, Tossa $\left(\mathrm{V}_{6}\right.$ to $\left.\mathrm{V}_{8}\right)$ and $\mathrm{Kenaf}_{(\mathrm{V}}\left(\mathrm{V}_{9}\right.$ to $\mathrm{V}_{12}$ ). The single factor experimental data was laid out in a completely randomized block design with three replications and the means were adjudged by DMRT at 5\% level of probability. Varietals performance of Jute and Kenaf were showed statistically significant variation among the studied whole growth, yield and yield attributing traits. Among the varieites, the Jute variety BJC-7370 porduce the tallest plant $(299.0 \mathrm{~cm})$, medium base diameter $(27.04) \mathrm{mm}$ and longest root $(28.44 \mathrm{~cm})$ at harvest. Dry matter viz. root $\left(13.51 \mathrm{~g} \mathrm{plant}^{-1}\right), \mathrm{stem}^{(48.51 \mathrm{~g}}$ plant $\left.^{-1}\right)$, leaf (12.87 g plant $\left.^{-1}\right)$ and TDM (74.89 g plant $\left.^{-1}\right)$ production had also higher in BJC-7370. However, base diameter (26.84 mm) and dry weight of leaf (12.37 g plant $\left.{ }^{-1}\right)$ were statistically similar with Kenaf variety HC-3. The Jute variety BJC-7370 had also showed greater results on various yield characters viz. green (whole plant) weight $\left(232.4 \mathrm{~g} \mathrm{plant}^{-1}\right)$ and stick $\left(58.97 \mathrm{~g} \mathrm{plant}^{-1}\right)$ and fiber yield $(58.97 \mathrm{~g}$ plant $\left.{ }^{1}\right)$.The Kenaf variety $\mathrm{HC}-3$ was also showed fiber $\left(19.91 \mathrm{~g}\right.$ plant ${ }^{-1}$ ) production. So, therefore, the Jute variety BJC-7370 and Kenaf vareity HC-3 gave understanding superiority on growth, yield and yield contributing traits as well as higher seed and fiber yield under the AEZ-13. So, Jute variety BJC-7370 or Kenaf variety HC-3 would be more successful productive variety in AEZ- 13 compare to the other studied Jute and Allied fiber varieties.
\end{abstract}

Keywords: Jute; Kenaf; Mesta; Allied fiber; Southern part; Bangladesh.

\section{Introduction}

Jute is an important cash and fibre crop which belongs to the family Tiliaceae and genus Corchorus. There are two cultivated species of jute are Corchorus capsularis (Deshi jute) and Corchorus olitorius (Tossa jute). The commercial product of the fibre derived from these two species of genus Corchorus, among 40 species are distributed throughout the tropics (Alim 1978). Jute is the second important fibre crop of the world (Saha 1996) and it is generally known as golden fibre of Bangladesh as it contributed as lion share to the economy. Khatun (2010) also reported that Jute, Kenaf, and Mesta are the second most important natural fibers next to cotton. Jute grows under wide variation of climatic conditions and stress of tropic and subtropics. It is grown in Bangladesh, India, Myanmar, Nepal, China, Taiwan, Thailand, Vietnam, Cambodia, Brazil and some other countries. Jute and kenaf are cultivated almost exclusively in developing countries of East Asia and in some parts of Latin America. Of the total world jute production, five producing countries, namely Bangladesh, China, India, Nepal and Thailand account for about $95 \%$. These countries also account for $90 \%$ of export of jute products (Khatun, 2010). In Bangladesh, the area of Jute cultivation is $17,51,325$ acres (7, 08,723 hactares) of land where the total production is $83,95,840$ bales per annum with an average yield of 4.79 bales per acre ( 11.846 bales per hec- tare) which was found by the statistical report of 2010-11 (BBS, 2012).

The jute that grows in relatively low land and is sown during the period of March and April is called Capsularis, and the jute usually planted during the period of April and May is said Olitorius. The most significant characteristics of jute are that it is free from health hazards and environmental pollution.

It is also versatile, durable, reusable, cheap and superior to synthetics. It is regarded as the best natural substitute for nylon and polypropylene. Recently it has been termed as the major solution for the eco-friendly product of tomorrow (Mollah, 2010). Jute fibre is used for making gunny bags, sacking, carpet backing cloths, mats blankets, furnishing fabrics and packing materials as an alternative to polyethyline bags. It is also used as micro-crystal cellulose in pharmaceutical laboratories and jute Zeo-Textice for the constructions (Islam, et al., 2011).

Kenaf, scientifically known as Hibiscus cannabinus L. is one of the most potential annual crop planted throughout the world. It is a member of the Hibiscus family (Malvaceae) and indigenous to Africa. Kenaf is an annual fibre crop of tropical origin (Hamid, 2009). The genus Hibiscus is widespread, comprising some 200 annual and perennial species.

Tahery et al. (2011) reported that the Kenaf (Hibiscus cannabinus L.) is one of the important fiber crops next to cotton which is cul- 
tivated for its core and bast fibres. Recently, the interest in growing kenaf has been increased throughout the world for its elevated fiber content (Alexopoulou et al., 2000). Kenaf is a fast growing crop and has high potential to be used as an industrial crop globally since it contains higher fiber materials or lignocellulosic material (Manzanares et al., 1996). The residual core fraction can be used as biomass for energy production (Danalatos and Archontoulis, 2005). Actually, kenaf is traditionally grown in east-central Africa, west Asia and in several southern states of America for fiber and oil seed (20\% oil content) production; whereas it comprises an excellent forage crop (Phillips et al., 1989), containing $18-30 \%$ crude leaf protein and stalk protein $5.8-12.1 \%$ (Phillips et al., 1989).

In Bangladesh, the major part of agricultural researches on jute, kenaf and Mesta are being conducted in Bangladesh Jute Research Institute (BJRI). It is the oldest research institute of the country and has been conducting researches in agricultural aspects on two bast fibre producing species of jute namely, Corchorus olitorius (tossa jute) and C. capsularis (deshi jute) and two species of Hibiscus namely. $\mathrm{H}$. cannabinus (kenaf) and $\mathrm{H}$. sabdariffa (mesta/roselle).

In Bangladesh about 2.8 million hectares constitute coastal and offshore areas (Karim et al. 1982) including Patuakhali region. These areas are affected by different degrees of salinity (Karim et al 1990). The salinity developed in soil adversely affects the growth and yield of different crop plants. Morphological characters namely plant height, total tillers, root, shoot, panicle length, grain weight panicle-1, grain size and quality and quantity of grains decrease progressively with increase in salinity level (Abdullah et al. 2001) Seed germination is affected by the increase in salinity (Purhpan and Rangasamy, 2002).

Islam (2005) evaluated jute mutants CM-107, P-26(5), CM-61, CM-67, CM-652, BINA deshi pat-2, CM-443 and P-81(2) under at three salinity levels and observed that plant height, number of leaves, leaf area, root, stem, and leaf dry weight, total dry matter decreased with the increase in salinity levels compared to control The mutants of CM-443 and P-26(5) were proved to be moderately salt tolerant. So, increasing jute production it is urgently needed to extent the cultivation of jute to all possible areas of Bangladesh But the cultivation of jute crop in the study area (Patuakhali) is not easy because of the lack of salinity tolerant varieties.

\section{Materials and methods}

\subsection{Experimental site}

The experimental field located at $22^{0} 37^{\prime} \mathrm{N}$ latitude and $89^{\circ} 10^{\prime} \mathrm{E}$ longitudes at Genetic Tidal Floodplains and falls under Agroecological Zone "AEZ- 13". The study locations also lie under Ganges Tidal Floodplain AEZ (AEZ No. 13). This region occupies an extensive area of tidal floodplain land in the south-west of the country. The total coverage of this region is $17066 \mathrm{~km}$ square with a total land mass of 1706600 ha (when Barisal, Jhalakathi, Pirojpur, Patuakhali, and Barguna are included). The western coastal zone (AEZ-13) is covered by the Sundarbans mangrove forest, covering greater Khulna and part of Patuakhali district. The area lies at 0.9 to 2.1 meter above mean sea level (Iftekhar \& Islam, 2004).

\subsection{Soil}

Soil characteristics of the western coastal zone are silty loams or alluvium. Islam (2005) mentioned that mangrove dominated coastal areas have developed on soil formations of recent origin consisting of alluvium washed down from the Himalayas. So, the experimental field was a medium high land with silty caly loam textured soil having $\mathrm{pH}$ value of 6.8. Non-calcareous Grey Floodplain Soils (Saline Phase): This general soil type occupies the major areas of the Ganges Tidal Floodplain AEZ. The organic matter content is low $(0.93 \%)$ in most cases. Deficiency of $\mathrm{N}$ is acute and widespread. Status of exchangeable $\mathrm{K}$ is almost satisfactory, consequently $\mathrm{K}$ deficiency is less frequently observed. Regional variation in $\mathrm{P}$ status is also remarkable. $\mathrm{P}$ deficiency is generally prevalent in Satkhira, Patuakhali, Barguna and Bagerhat districts while in Khulna district supply of $P$ is almost satisfactory. This is due to the presence of a large amount of $\mathrm{K}$ bearing minerals in these soils. $\mathrm{N}$ is deficient in all the areas under this soils. $\mathrm{P}$ is generally deficient, while $\mathrm{S}$ deficiency is observed less frequently. Zinc deficiency is prevalent in all the soil series because of high $\mathrm{pH}$ values.

\subsection{Climate}

The experimental area falls under the sub-tropical climate, which is characterized by high temperature and humidity, heavy rainfall with occasional gusty winds in the Kharif season (AprilSeptember) and less rainfall associated with moderately low temperature during the rabi season (October-March) (Biswas, 1987).

\subsection{Experimental materials}

As planting materials, the seeds of eight Jute and four Kenaf varieties were used for this study which was collected from Bangladesh Jute Research Institute (BJRI), Farmgate, and Dhaka and also from the local farmer of Patuakhali District.

\subsection{Parameters measured}

\subsection{Number of plants $m-2$}

Number of plants $\mathrm{m}^{-2}$ were count at harvest stage and their average number of plants $\mathrm{m}^{-2}$ data was calculated.

\subsection{Plant height (cm)}

Plant height was recorded from 10 randomly selected plants from each plot and was taken at harvest (102 DAS). The effective plant height was considered from ground level to the top of the leaf at vegetative phase at harvest stage. Plant height data was measured by a meter scale and converted into $\mathrm{cm}$.

\subsection{Base diameter $(\mathbf{m m})$}

The base diameter of plant was measured with a meter scale as the horizontal distance covered by the plant. The data were recorded from ten selected plants at harvest and mean value was counted and was expressed in centimeter ( $\mathrm{mm}$ ).

\subsection{Root length (cm)}

Randomly selected ten plants of each plot and their roots were removed from the plants and then the roots of the selected plant were measured in centimeter $(\mathrm{cm})$ scale. Finally, mean value of them was recorded and the data was recorded at harvest.

Dry weight of root (g plant $\left.{ }^{-1}\right)$

Immediately after harvest of ten plants, the roots were detached from the plants and cleaned thoroughly by washing with tap water. Collected roots were dried in sun for 23 days and then oven dried for 72 hours at $80^{\circ} \mathrm{C}$. Immediately after oven drying, the dried roots were weighed and the dry matter content of the roots was recorded and converted to $\mathrm{g}_{\text {plant }}{ }^{-1}$.

\subsection{Dry weight of stem (g plant-1)}

The stem dry matter weight was taken by oven dry method. Randomly selected ten plants sample collected from each plot during harvest. They were gently washed to remove sand and dust particles adhere to the plants. The selected plants were cut into small pieces and then the water adhere to the plants were soaked with paper towel. After then the samples were kept in an oven at $70^{\circ} \mathrm{C}$ 
for 72 hours to attain constant weight and the dry weights were recorded and converted into g plant ${ }^{-1}$.

\subsection{Dry weight of leaf (g plant-1)}

Immediately after harvest, the leaves were cleaned thoroughly by washing with water. The leaves of randomly selected ten plants were taken and then sun dried for two days. Sun dried samples were then put in paper packets and oven dried for 72 hours at 70 to $80^{\circ} \mathrm{C}$ in an oven. After oven drying, leaves were weighed. An electric balance was used to record the dry weight of leaves. Finally their calculated average data was converted into g plant ${ }^{-1}$.

\subsection{Total dry matter (TDM) (g plant-1)}

The plant parts such as leaves, stems and roots were detached from the plants and were kept separately in oven at $82^{\circ} \mathrm{C}$ for 72 hours. The oven dried samples were weighed for dry matter production. The total dry matter production was calculated from the summation of dry matter produced by leaves, stem and roots and converted into g plant ${ }^{-1}$.

\subsection{Fresh weight (g plant-1)}

The plants of Jute and Allied fiber of central $1 \mathrm{~m}^{2}$ of each plot were taken after harvest and then their fresh weight was recorded by using electric balance as per treatments. Their calculated fresh weight was then expressed in g plant $^{-1}$.

\subsection{Stick weight (g plant-1)}

Stick weight was determined from the central $1 \mathrm{~m}^{2}$ of each plot After harvesting, leaves, stems (stick) and roots were detached and the weight of stick were recorded and finally converted to g plant

\subsection{Fiber yield (t ha-1)}

The fibers of the selected central $1 \mathrm{~m}^{2}$ Jute and Kenaf varieties were taken after retting and then their fiber weight was recorded Their calculated average weight was then expressed in $\mathrm{tha}^{-1}$.

\section{Results and discussion}

\subsection{Number of plants $m-2$}

Analysis of variance data on number of plants plot ${ }^{-1}$ significantly influence by the various Jute and Allied Fiber varieties. Among the varieties, the variety BJC-7370 obtained significantly the maximum number of plants $\mathrm{m}^{-2}$ (24.19) followed by the variety $\mathrm{HC}-95$ (23.05), $\mathrm{HC}-2$ (22.67) and BJC-2142 (22.29) where $\mathrm{HC}-95, \mathrm{HC}-2$ and $\mathrm{BJC}-2142$ were statistically more or less similar.

\subsection{Plant height (cm)}

It is evident from the data that the varieties differed significantly with respect to plant height in this study (Fig. 2). The tallest plant $(299.0 \mathrm{~cm})$ was recorded from the variety BJC-7370 which was followed by the variety $\mathrm{HC}-3(291.0 \mathrm{~cm})$ and BJC-2142 $(288.0$ $\mathrm{cm})$ where $\mathrm{HC}-3$ and $\mathrm{BJC}-2142$ were statistically identical. On the other hand, significantly the shortest plant $(251.0 \mathrm{~cm})$ was found from the both $\mathrm{O}-9897$ and O-795 varieties. In general, plant height is the most efficient morphological character which is directly related to greater fiber yield of Jute or Kenaf as well as the tallest plant maximizing the fiber yield of Jute or Kenaf. The variety BJC- -7370 showed higher adaptability with the climatic condition and also with the soil of southern part of Bangladesh or salinity affected studied area than other varieties. Similar findings were also obtained by Pervin and Haque (2012) who observed that the analysis of variance significant differences among the genotypes for plant height. The variation was also found due to its genetic makeup.

\subsection{Base diameter $(\mathrm{mm})$}

Analysis of variance data was present in indicated significant variation due to the effect of different Jute and Allied Fiber varieties with the respect of base diameter in this study (Table 1). Base diameter is also important character for fiber yield of Jute or Kenaf varieties in case of the higher base diameter produce the better thickness of fiber which will ensure the higher production of fiber. Among the Jute and Allied Fiber varieties, the highest base diameter $(27.04 \mathrm{~mm})$ was found from the variety $\mathrm{HC}-2$ which was statistically at per similar rank with the variety $\mathrm{HC}-3(26.84 \mathrm{~mm})$. Among the other varieties, all the variety differed significantly with each other (Table 1). On the other hand, significantly the lowest base diameter $(17.48 \mathrm{~mm})$ was noticed from the variety $\mathrm{O}-$ 9897. Significant varietals performance on base diameter were also obtained by Pervin and Haque (2012); Islam (2007 and 2004); Azad-ud-doula Prodhan et al. (2001) in jute and Hossain et al. (2012a and 2012b) in Kenaf.

\subsection{Length of root $(\mathrm{cm})$}

Analysis of variance data on length of root differed significantly among the Jute and Allied Fiber varieties (Table 1). The longest root $(28.44 \mathrm{~cm})$ was observed in $\mathrm{BJC}-7370$ which was closely followed by the variety $\mathrm{HC}-3(27.89 \mathrm{~cm}), \mathrm{HC}-95(27.45 \mathrm{~cm})$ and $\mathrm{BJC}-2142(27.17 \mathrm{~cm})$ whereas the variety $\mathrm{HC}-95$ and BJC-2142 were statistically more or less similar. In contrast, the shortest root $(23.67 \mathrm{~cm})$ was taken from the variety $\mathrm{O}-9897$ which was also statistically identical with the variety $\mathrm{HC}-2(24.09 \mathrm{~cm})$. Those varieties were also closely followed by $\mathrm{O}-795(24.88 \mathrm{~cm})$ and CVE-3 $(25.31 \mathrm{~cm})$ where $\mathrm{O}-795$ and CVE-3 were statistically at per similar rank.

\subsection{Dry weight of root (g plant-1)}

The analysis of variance data on dry weight of root showed significant difference due to the effect of Jute and Allied Fiber varieties which variation data was present in (Table 2). From the table 2, it was found that the variety BJC-7370 had higher (13.51 $\left.\mathrm{g} \mathrm{plant}^{-1}\right)$ dry weight of root which was closely followed by $\mathrm{HC}-3$ (13.11 g plant $\left.{ }^{-1}\right)$, BJC-83 (12.98 g plant $\left.^{-1}\right)$ and O-72 (12.51 g plant $\left.{ }^{-1}\right)$. However, the variety $\mathrm{HC}-3, \mathrm{BJC}-83$ and $\mathrm{O}-72$ were statistically differed among each other. On the other hand, significantly the lowest weight of dry root $\left(10.69 \mathrm{~g} \mathrm{plant}^{-1}\right)$ was found from the variety BJC2142 which was statistically identical with O-9897 (10.87 g plant $\left.^{-1}\right)$. These varieties were also closely followed by $\mathrm{HC}^{-}-2(11.07 \mathrm{~g}$ plant $\left.{ }^{1}\right)$ and $\mathrm{CVL}^{-1}\left(11.52 \mathrm{~g} \mathrm{plant}^{-1}\right)$ but they were statistically differed. This variation was found due to the genetic makeup of the Jute and Allied fiber varieties. Similarly, Islam et al. (2011) reported that dry weight of root differed significantly among the varieties where $\mathrm{O}-$ 9897 recorded the lowest weight of dry root.

\subsection{Dry weight of stem ( $g$ plant-1)}

Dry weight of stem was significantly influence by the different Jute and Allied Fiber varieties which variation data was present in Table 2. And indicated significant difference and the variety BJC7370 had higher $\left(48.51 \mathrm{~g} \mathrm{plant}^{-1}\right)$ in dry weight of stem than other varieties. However, it was statistically closely followed by the variety BJC-2142 (47.51 g plant $\left.{ }^{-1}\right), \mathrm{HC}-3$ (46.87 g plant $\left.^{-1}\right)$, BJC83 (46.67 $\left.\mathrm{g} \mathrm{plant}^{-1}\right)$ and $\mathrm{HC}-95$ (45.87 g plant $\left.^{-1}\right)$ whereas the variety $\mathrm{HC}-3$ and $\mathrm{BJC}-83$ were statistically significant at $5 \%$ level The tallest plant and higher base diameter confirm higher dry weight of stem. Similarly, Islam et al. (2011) reported that dry weight of stem differed significantly among the varieties where O-9897 recorded the lowest weight of dry stem. 
Table 1: Effect of Different Jute and Allied Fiber Varieties on Base Diameter and Root Length at Harvest

\begin{tabular}{lll}
\hline Variety & Base diameter $(\mathrm{mm})$ & $\begin{array}{l}\text { Length of root }(\mathrm{cm}) \\
24.89 \mathrm{de}\end{array}$ \\
\cline { 1 - 2 } CVL-1 & $22.11 \mathrm{c}$ & $24.09 \mathrm{e}$ \\
HC-2 & $27.04 \mathrm{a}$ & $23.67 \mathrm{e}$ \\
$0-9897$ & $17.48 \mathrm{~g}$ & $25.31 \mathrm{de}$ \\
CVE-3 & $21.53 \mathrm{~cd}$ & $26.39 \mathrm{bcd}$ \\
$0-72$ & $18.64 \mathrm{f}$ & $28.44 \mathrm{a}$ \\
BJC-7370 & $20.01 \mathrm{e}$ & $27.45 \mathrm{abc}$ \\
HC-95 & $19.57 \mathrm{e}$ & $26.01 \mathrm{~cd}$ \\
BJC-83 & $21.49 \mathrm{~cd}$ & $26.31 \mathrm{bcd}$ \\
VM-1 & $23.88 \mathrm{~b}$ & $24.88 \mathrm{de}$ \\
$0-795$ & $23.89 \mathrm{~b}$ & $27.89 \mathrm{ab}$ \\
HC-3 & $26.84 \mathrm{a}$ & $27.17 \mathrm{abc}$ \\
BJC-2142 & $21.24 \mathrm{~d}$ & $* *$ \\
Sig. Level & $* *$ & 3.7 \\
CV $(\%)$ & 5.19 &
\end{tabular}

$* *=$ Significant at $1 \%$ level of probability

\subsection{Dry weight of leaf (g plant-1)}

The analysis of variance data on dry weight of leaf showed significant different due to the effect of Jute and Allied Fiber varieties. From the table 2, it was found that the variety BJC-7370 observed the highest weight of dry leaf (12.87 $\left.\mathrm{g} \mathrm{plant}^{-1}\right)$ which was statistically identical with $\mathrm{HC}-3$ (12.37 g plant $\left.^{-1}\right)$. The variety BJC-7370 and $\mathrm{HC}-3$ were also closely followed by the variety $\mathrm{HC}-95$ (12.13 g plant $\left.^{-1}\right)$ and BJC-73 (11.7 g plant $\left.^{-1}\right)$ where they were also statistically identical. The study was also obtaiend by Islam et al. (2011); Hayder talukder et al. (2001a and 2001b) in Jute varieties and Pushpa et al. (2013a and 2013b); Hossain et al. (2012a and 2012b) and many other scientist in Kenaf varieties.

\subsection{Total dry matter-TDM (g plant-1)}

Total dry matter (TDM) weight data was significantly influenced by the effect of Jute and Allied Fiber varieties (Table 2). Among the varieties, the higher TDM (74.89 $\mathrm{g} \mathrm{plant}^{-1}$ ) was observed in BJC-7370 which was closely followed by BJC-2142 (72.88 g plant $\left.{ }^{-1}\right), \mathrm{HC}-3$ (72.35 $\left.\mathrm{g} \mathrm{plant}^{-1}\right)$ and BJC-83 (71.52 $\left.\mathrm{g} \mathrm{plant}^{-1}\right)$ whereas BJC-2142 and $\mathrm{HC}-3$ were statistically at per similar rank. Similarly, Islam et al. (2011) reported that total dry matter differed significantly among the Jute varieties where O-9897 recorded the lowest weight of TDM. Similar results were also obtained by Pushpa et al. (2013a and 2013b); in Kenaf varieties.

Table 2: Effect of Different Jute and Allied Fiber Varieties on Various Dry Weight Characters at Harvest

\begin{tabular}{|c|c|c|c|c|}
\hline Variety & Dry weight of root $\left(\mathrm{g} \mathrm{plant}^{-1}\right)$ & Dry weight of stem $\left(\mathrm{g}\right.$ pant $\left.^{-1}\right)$ & Dry weight of leaf $\left(\mathrm{g}\right.$ plant ${ }^{-1}$ ) & Total dry matter $\left(\mathrm{g}\right.$ plant $\left.^{-1}\right)$ \\
\hline CVL-1 & $11.52 \mathrm{def}$ & $41.73 \mathrm{fgh}$ & 11.12 bcd & 64.37 efg \\
\hline $\mathrm{HC}-2$ & 11.07 ef & $40.97 \mathrm{gh}$ & $10.67 \mathrm{~d}$ & $62.71 \mathrm{fg}$ \\
\hline 0-9897 & $10.87 \mathrm{f}$ & $40.11 \mathrm{~h}$ & $10.08 \mathrm{~d}$ & $61.09 \mathrm{~g}$ \\
\hline $0-72$ & $12.51 \mathrm{abcd}$ & $43.51 \mathrm{defg}$ & $10.81 \mathrm{~cd}$ & 66.83 def \\
\hline BJC-7370 & $13.51 \mathrm{a}$ & $48.51 \mathrm{a}$ & $12.87 \mathrm{a}$ & $74.89 \mathrm{a}$ \\
\hline $\mathrm{HC}-95$ & $12.03 \mathrm{cde}$ & 45.87 abcd & $12.13 \mathrm{ab}$ & $70.03 \mathrm{bcd}$ \\
\hline BJC-83 & $12.98 \mathrm{abc}$ & $46.67 \mathrm{abc}$ & $11.87 \mathrm{abc}$ & $71.52 \mathrm{abc}$ \\
\hline VM-1 & $12.19 \mathrm{bcd}$ & 44.87 bcde & $11.11 \mathrm{bcd}$ & $68.17 \mathrm{cde}$ \\
\hline $0-795$ & $11.97 \mathrm{cde}$ & $44.11 \mathrm{cdef}$ & $10.92 \mathrm{~cd}$ & 67.00 de \\
\hline $\mathrm{HC}-3$ & $13.11 \mathrm{ab}$ & $46.87 \mathrm{abc}$ & $12.37 \mathrm{a}$ & $72.35 \mathrm{ab}$ \\
\hline BJC-2142 & $10.69 \mathrm{f}$ & $47.51 \mathrm{ab}$ & $12.01 \mathrm{ab}$ & $72.88 \mathrm{ab}$ \\
\hline Sig. Level & $* *$ & $* *$ & $* *$ & $* *$ \\
\hline CV (\%) & 4.79 & 3.77 & 4.99 & 3.33 \\
\hline
\end{tabular}

$* *=$ Significant at $1 \%$ level of probability.

\subsection{Fresh weight (g plant-1)}

The highest fresh green weight (232.4 g plant $\left.^{-1}\right)$ was taken from the variety BJC -7370 which was closely followed by the variety BJC-2142 (229.2 g plant $\left.^{-1}\right)$. Among the other varieties, the variety O-9897 observed significantly the lowest green weight $\left(167.3 \mathrm{~g} \mathrm{plant}^{-1}\right)$ which was also closely followed by the variety CVE-3 (172.4 g plant $^{-1}$ ) (Fig. 3). This variation was found due to its genetic makeup and also the variation of plant height, base diameter, leaf production and branch production. Pervin and Haque (2012); Islam (2007) reported that the green weight data were statistically similar among the Jute varieties. Lorenzo et al. (2011) also found similar results where they found that wholeplant biomass (DB) differed significantly among the varieties.

\subsection{Stick weight (g plant-1)}

Analysis of variance on stick weight was significantly influenced due to the effect of different Jute and Allied Fiber varieties (Fig. 4). From the Fig. 4, it was observed that the variety BJC-7370 further recorded the higher stick weight $\left(58.97 \mathrm{~g} \mathrm{plant}^{-1}\right)$ which was closely followed by HC-3 $\left(57.98 \mathrm{~g}\right.$ plant $\left.^{-1}\right)$. Similarly, the lowest green weight $\left(40.42 \mathrm{~g} \mathrm{plant}^{-1}\right)$ was observed from the variety O-9897 which was statistically differed among other varieties. This variation was found due to its genetic make-up and also the variation of plant height.

\subsection{Fiber yield (t ha-1)}

Analysis of variance on fiber yield was significantly influenced by the different modern varieties of Jute and Allied Fiver. Among the varieties, fiber yield had higher in BJC-7370 (4.93 t ha-1) which was statistically differed from other varieties. These were also found due to its genetic makeup and higher regional adaptability with climatic condition and soil properties of the experimental field of the present study. Finally, the variety BJC-7370 had outstanding superiority for plant growth, higher seed and fiber yield over other varieties in this study.

Table 3: Effect of Different Jute and Allied Fiver Varieties on Yield and Yield Contributing Characters at Harvest

\begin{tabular}{lll}
\hline Variety & $\begin{array}{l}\text { Fiber weight } \\
\mathrm{g}^{-1} \text { plant }^{-1}\end{array}$ & $\mathrm{t} \mathrm{ha}^{-1}$ \\
\hline CVL-1 & $17.15 \mathrm{ef}$ & $3.500 \mathrm{ef}$ \\
HC-2 & $16.71 \mathrm{fg}$ & $3.210 \mathrm{~h}$ \\
$0-9897$ & $15.31 \mathrm{~h}$ & $2.540 \mathrm{i}$ \\
CVE-3 & $15.91 \mathrm{gh}$ & $3.360 \mathrm{~g}$ \\
$0-72$ & $17.98 \mathrm{de}$ & $3.530 \mathrm{e}$ \\
BJC-7370 & $20.37 \mathrm{a}$ & $4.930 \mathrm{a}$ \\
HC-95 & $18.48 \mathrm{~cd}$ & $4.260 \mathrm{c}$ \\
BJC-83 & $19.11 \mathrm{bc}$ & $4.220 \mathrm{c}$ \\
VM-1 & $18.11 \mathrm{de}$ & $3.620 \mathrm{e}$ \\
$0-795$ & $18.29 \mathrm{~cd}$ & $3.380 \mathrm{fg}$ \\
HC-3 & $19.91 \mathrm{ab}$ & $4.510 \mathrm{~b}$ \\
BJC-2142 & $17.99 \mathrm{de}$ & $4.010 \mathrm{~d}$ \\
Sig. Level & $* *$ & $* *$ \\
CV $(\%)$ & 3.03 & 2.07 \\
\hline
\end{tabular}

$* *=$ Significant at $1 \%$ level of probability. 


\section{Conclusion}

In the present research, it is clear that the Tossa Jute variety BJC7370 had more efficient on the whole growth, yield and yield attributing traits. BJC-7370 or Kenaf variety $\mathrm{HC}-3$ would be most suitable variety under the AEZ-13 or the climatic or soil (regional) condition of Southern Part of Bangladesh. So, I strongly recommended that Jute variety $\mathrm{BJC}-7370$ or Kenaf variety $\mathrm{HC}-3$ would be more successful productive variety in AEZ- 13 or regional condition of Southern part of Bangladesh.

\section{Acknowledgement}

Special Thanks to Dr. Md. Fazlul Hoque, Professor, Department of Soil Science and Mohammad Kabirul Islam, Associate Professor, Department of Soil Science, Patuakhali Science and Technology University for his suggestions, guidance, and cooperation.

\section{References}

[1] Alim, A. 1978. A Hand Book of Bangladesh Jute. Associated Printer Ltd., 311 Johnson Road, Dhaka. p. 10.

[2] Abdullah, Z., Khan, M.A. and Flowers, T.Z. 2001. Causes of sterility in seed set of rice under salinity stress. J. Agron. Crop Sci. 167(1): 25-32. https://doi.org/10.1046/j.1439-037X.2001.00500.x.

[3] Alexopoulou, E., Christou, M., Mardikis, M. and Chatziathanassiou, A. 2000. Growth and yields of kenaf varieties in central Greece. Industrial Crops and Prod., 11: 163-172. https://doi.org/10.1016/S0926-6690(99)00064-3.

[4] Azad-ud-doula Prodhan, A.K.M., Rahman, M.L. and Haque, M.A 2001. Effect of Water Stresses on Growth Attributes in Jute II. Plant Based Diameter. Pak. J. Biol. Sci., 4: 660-664 https://doi.org/10.3923/pjbs.2001.660.664.

[5] Biswas, P.K. 1987. A study on the relative merits of mixed cropping under two levels of irrigations. MS Thesis, Dept. Agron. Bangladesh Agric. Univ. Mymensingh. p. 38-40.

[6] BBS (Bangladesh Bureau of Statistics). 2012. Statistics Pocket Book of Bangladesh (2010-11). Bangladesh Bureau of Statistics Division, Govt. of the People's Republic of Bangladesh. p. 91-92.

[7] Danalatos N.G. and Archontoulis S.V. 2005. Sowing time and plan density effects on growth and biomass productivity of two kenaf varieties in central Greece. Intl. Confc. on Industrial Crops and $\mathrm{Ru}-$ ral Development, Sept. 17-21, Murcia, Spain, (online available at http://www.aaic.org/05progrm.htm).

[8] Hayder Talukder, F.A., Sontosh Chandra Chanda, Golam Sarwar, A.K.M., Bhander, P.K. and Islam, M.N. 2001a. Early vegetative growth and fibre yield in tossa Jute (Corchorus olitorius L.). Pak. J. Biol. Sci., 4: 665-667. https://doi.org/10.3923/pjbs.2001.665.667.

[9] Hayder Talukder, F.A., Sontosh Chandra Chanda, Shahidul Islam, M. and Golam Sarwar, A.K.M. 2001b. Effect of Seed Filling Period on Quality of White Jute (Corchorus capsularis L.) Seed. J. Biol Sci., 1: 365-367. https://doi.org/10.3923/jbs.2001.365.367.

[10] Hossain, M.D., Hanafi, M.M., Jol, H. and Hazandy, A.H. 2012a. Effects of carbon levels on shoot growth and root characteristics of different kenaf (Hibiscus cannabinus L.) varieties grown on sandy bris soil. African J. Biotech., 11(25): 6703-6709. https://doi.org/10.5897/AJB11.3640.

[11] Hossain, M.D., Hanafi, M.M., Jol, H. and Jamal, T. 2011b. Dry matter and nutrient partitioning of kenaf (Hibiscus cannabinus L.) varieties grown on sandy bris soil. Aus. J. Crop Sci., 5(6): 654-659.

[12] Hamid, H. 2009. Effects of Different Fertilizer Application Level on Growth and Physiology of Hibiscus cannabinus L. (Kenaf) Planted on BRIS Soil. Agril. Sci., 1(1): 121-131.

[13] Islam, M.T., Begum, M.B. and Islam, M.O. 2011. Screening of Jute mutants for salinity tolerance. Intl. J. Sustain. Crop Prod., 6(2): 611.

[14] Islam, M.M. 2007. Variebility and path coefficient analysis in jute (Corchorus olitorius L.) of indigenous origin. Digital Archive on Agricultural Theses and Journal. $N^{\circ}$ Catalog: SAU200701_112. Sher-E-Bangla Agricultural University, Sher-E-Bangla Nagar, Dhaka

[15] Islam, M.R. \& Ahmad, M. 2004. Living in the coast: problems, opportunities and challenges. Program Dev. Office for Integrated Coastal Zone Management Plan Project; Water Resources Planning Organization. Dhaka, Bangladesh.
[16] Islam, M.S., Nasreen, A., Begum, S. and Haque, S. 2004. Correlated response and path analysis in Tossa jute (Corchorus olitorius L.). Bangladesh J. Bot., 33(2): 99-102.

[17] Islam, M. Z, Baset Mia, M. A., Akter, A. and Rahman, M. H. 2007. Biochemical attributes of mutant rice under different saline levels. International Journal of Sustainable Crop Production. 2(3): 17-21

[18] Islam, R., Ahmad, S., Rashid, H. 2005 Bangladesh Jute Research Institute, Dhaka, Bangladesh. Ann. Rep. 2005-2006. pp. 35-36.

[19] Karim, Z., Hussain, S.G. and Ahmed, M. 1990. Salinity problems and crop intensification in the coastal regions of Bangladesh (BARC). p. 1.

[20] Karim, Z., Saheed, S.M., Salahuddin, A.B.M., Alam, M.K. and Haque, A. 1982. Coastal saline soils and their management in Bangladesh; BARC Publication No. 8.

[21] Khatun, A. 2010. Recent agricultural developments in jute, kenaf and mesta through traditional and biotechnological approaches. $\mathrm{Ge}-$ netic Resources and Seed Division, Bangladesh Jute Research Institute, Manik Mia Avenue, Dhaka 1207, Bangladesh.

[22] Manzanares, M., Tenorio, J.L. and Ayerbe, L. 1996. Sowing time, cultivar, plant population and application of $\mathrm{N}$ fertilizer on kenaf in Spain's central plateau. Biomass Bioenerg. 12: 263- 271. https://doi.org/10.1016/S0961-9534(96)00078-5.

[23] Mollah, M.S.A. 2010. Report on The Cost of Production of Jute Crop 2008-09. Updating and Extension of Agriculture Cluster Plots and Survey of Cost of Production Project (UCPSCP). Planning Div., Ministry of Planning. pp. $9-10$.

[24] Pervin, N. and Haque, G.K.M.N. 2012. Path Coefficient Analysis for fibre Yield Related Traits in Deshi Jute (Corchorus capsularis L.). Intl. Res. J. App. Life Sci., 1(3): 72-77.

[25] Phillips, W., Rao, S. and Dao, T. 1989. Nutritive value of immature whole kenaf and mature kenaf tops for growing ruminants. Procc. Assoc. Adv. Ind. Crops. An. Conf., Illinois.

[26] Purhpan, R. and Rangasamy, S.R.S. 2002. In vivo response of rice cultivars to salt strees. J. Ecobiol. 14(3): 177-182.

[27] Pushpa, K., Krishna Murthy, N. and Krishna Murthy, R. 2013a. Growth and Yield Parameters of Mesta Varieties as Influenced by Spacing and Nutrient Sources. J. Agril. Sci., 5(3): 105-110. https://doi.org/10.5539/jas.v5n3p105.

[28] Pushpa, K., Krishna Murthy, N. and Krishna Murthy, R. 2013b. Dry matter accumulation studies at different stages of crop growth in mesta (Hibiscus cannabinus). J. Agril. Sci., 5(3): 332-338.

[29] Saha. 1996. Effect of intercropping mustard, corriander, red amaranth and radish with late jute seed rate. MS Thesis, Department of Agronomy, Bangladesh Agricultural University, Mymensingh.

[30] Tahery, Y., Abdul-Hamid, H., Tahery, E., Deljoo, E. and Mogrilan, M. 2011. Comparative photosynthesis and transpiration of three varieties of Hibiscus cannabinus L. (Kenaf). African J. Agril. Res., 6(8): 2010-2014 